\title{
Growth Response and Ionic Regulation in Common Carp (Cyprinus Carpio L.) After Chronic Dietary Copper Exposure and Recovery
}

\section{Ajani EK ${ }^{1}$ and Akpoilih BU ${ }^{2 *}$}

${ }^{1}$ Department of Wildlife and Fisheries Management, University of Ibadan, Ibadan, Oyo State, Nigeria

${ }^{2}$ Department of Animal Science and Fisheries, University of Port Harcourt, Port Harcourt, Rivers State, Nigeria

\begin{abstract}
Effects of exposure of common carp juveniles (Cyprinus carpio L.) to dietary copper and its recovery rate were investigated with the aim of determining the growth and physiological impact. The fish were fed elevated copper diets (1000 mgCukg ${ }^{-1}$ and $2000 \mathrm{mgCukg}^{-1}$ as diet 2 and diet 3 respectively) and control diet ( $5 \mathrm{mgCukg}^{-1}$, as diet 1 ) for 42 days and were then fed the control diet for a further 21days. After 42days of exposure to elevated copper diets, growth performance examined showed that there was significant increase at $(p<0.05)$ in feed intake, \%body weight, weight gain and condition factor by fish fed diet 2 compared to diet 1 and diet 3 . There was, however, no difference in specific growth rate, feed conversion ratio, in all treatments $(p>0.05)$. Hepatosomatic index increased significantly in fish fed both elevated diets compared to control diet $(p<0.05)$. Recovery period on normal diet (control) showed no significant effect of copper recovery on fed intake, weight gain, \%body weight, specific growth rate and feed conversion ratio in all treatments $(p>0.05)$, but, fish fed diet 2 showed a significant reduction in condition factor compared to other diets $(p<0.05)$. Tissue $\mathrm{Na}^{+}, \mathrm{Ca}^{2+} \mathrm{K}^{+}$were disturbed throughout the experiment with sodium increasing from $257.82 \pm 2.50$ $\mu \mathrm{mol} / \mathrm{g}$ to $388.14 \pm 1.32 \mu \mathrm{mol} / \mathrm{g}$ and calcium increasing from $499.54 \pm 6.81 \mu \mathrm{molg}^{-1}$ to $1025.94 \pm 9.16 \mu_{\mathrm{molg}^{-1}} \mathrm{reducing}^{-1}$ gill copper from $11.63 \pm 0.37 \mathrm{mgCukg}^{-1}$ to $0.00 \pm 0.00 \mathrm{mgCukg}^{-1}$. Intestinal copper decreased from $14.93 \pm 0.1 \mathrm{mgCukg}^{-1}$ to $0.00 \pm 0.00 \mathrm{mgCukg}^{-1}$ as a result of sodium increasing from $130.30 \pm 5.12 \mu \mathrm{molg}^{-1}$ to $438.72 \pm 2.44 \mu_{\mathrm{molg}}{ }^{-1}$. The reduction in intestinal calcium was sodium dependent as increasing sodium decreased calcium absorption. Increased gill copper of the $1000 \mathrm{mgCukg}^{-1}$ diet exposed fish during exposure compared to the control was due to copper induced decrease in plasma ion regulatory sodium ( $\mathrm{Na}$ ATPase activity), which protected fish from direct toxicity effect and could also suggest another pathway other than the common $\mathrm{Na} / \mathrm{Cu}$ apical channel shared between sodium and copper through which copper binds to fish gill; diet 2 fish showing significant increase at $(p<0.05)$ in haematocrit, red blood cell, white blood cell and neutrophils, and a significant reduction in lymphocyte and mean cell hemoglobin compared to diet 1 and diet $3,(p<0.05)$. This increase in blood indices is indicative of stress onset to which fish fed diet 2 is subjected. Fish fed diet 3 showed significant reduction in haematocrit, red blood cell, white blood cell and increased lymphocyte $(p<0.05)$ and became anaemic with severe skin discoloration, indicative of a worsening effect of excess dietary copper exposure on the fish. There were not significant differences in moisture content of all tissues during and after copper exposure $(p<0.05)$, although, gills of fish fed diet 2 showed reduction in moisture compared to diet 1 and diet 3 -fed fish for both exposure and recovery phases, increasing from $75.3 \pm 3.20 \%$ to $79.5 \pm 6.44 \%$ after recovery for 21 days. Gills of fish fed diet 3 also increased post-exposure, indicative of protection of the structural integrity of the gill to prevent hypoxia through oxygen supply from water.
\end{abstract}

Keywords: Growth; Ionic chronic; Dietary copper Regulation; Exposure; Recovery; Common carp

\section{Introduction}

Copper is an essential trace element that plays a vital role in the physiology of animals for fetal growth and early post - natal development, for hemoglobin synthesis, connective tissue maturation especially in the cardiovascular system and in bones for proper nerve function and bone development, and inflammatory process. It is involved in different biochemical process of animal metabolism such as: enzyme - co enzyme catalytic reactions. It is associated with the function of a number of enzymes such as oxygenases including cytochrome $\mathrm{C}$ oxidase and copper- zinc super oxide dismutase [1,2] and; ion transport for instance with ceruloplasmin (ferroxidase1), a putative copper transport protein required for the incorporation of iron into transferring for it is transport in plasma [3].

It is an essential micronutrient for vertebrate animals especially fish, and has numerous functions, in addition to the ones stated above, in cellular biochemistry including vital roles in cellular respiration, and a cofactor for over 30 different enzymes [3]. Copper deficiency leads to physiological disturbance. Symptoms include depression of growth, anaemia, bowing of legs, spontaneous fractures, ataxia of new borns, Cardiac and vascular disorders and a depigmentation, decrease in some organs weight, depressed reproductive performance including egg production.Copper, though essential in fish diet, can be harmful when large single or daily intake occurs.

The dietary effect of copper varies from species to species [4-6] and has severally been reported for most temperate fish such as Salmon [4] and recently, Nile tilapia [7], but little or no information on the dietary copper exposure and recovery in common carp has been reported. In Salmon, toxic effect of dietary copper includes reduced growth [8] severe lesions in the gut at high concentration $\left(10 \mathrm{gKg}^{-1}\right.$ food) cell proliferation and metallothionein [1]. Fatty change in the liver of salmon as well as altered haematology has been severally reported that

*Corresponding author: Akpoilih BU, Department of Animal Science and Fisheries, University of Port Harcourt, Port Harcourt, Rivers State, Nigeria, Tel: +234(0)8134381645; E-mail: benjamin.akpoilih@uniport.edu.ng

Received November 14, 2011; Accepted May 24, 2012; Published May 26, 2012

Citation: Ajani EK, Akpoilih BU (2012) Growth Response and lonic Regulation in Common Carp (Cyprinus Carpio L.) After Chronic Dietary Copper Exposure and Recovery. J Environ Anal Toxicol 2:143. doi:10.4172/2161-0525.1000143

Copyright: $\odot 2012$ Ajani EK, et al. This is an open-access article distributed unde the terms of the Creative Commons Attribution License, which permits unrestricted use, distribution, and reproduction in any medium, provided the original author and source are credited. 
copper when in excess, is stored in the liver and tend to increase after feed withdrawal leading to hepatic cell lysis and release of cell content in the liver. This is confirmed by [7] Shaw and handy. In their report in Nile tilapia, the recovery phase on normal diet without copper was characterized by a reduction in intestinal and branchial copper level after dietary cooper exposure was confirmed by elevated copper concentration in the intestine, liver and gills.

Knox reported similar fatty changes in the liver of salmon, but there was altered hematology, contrary to report of [7] Shaw and Handy. Research on copper exposure and recovery in common carp would go a long way to add to sparse literature on dietary copper exposure and recovery in tropical fresh water and to know if difference in climate and region could account for differences in toxicity of dietary copper exposure at same level.

Dietary copper exposure in African catfish has also been reported severally, aqueous copper exposure and recovery on common carp [9]; aqueous cadmium exposure in common carp; aqueous zinc on common carp [10]; dietary copper exposure and recovery in Nile tilapia [7]; as well as threshold for excess dietary copper toxicity on fresh water fish excluding carp $[5,8]$ have all been reported. But to my knowledge and literature review, no study on the dietary copper exposure and recovery in common carp (L) has been reported. This present study will not only examine chronic dietary copper toxicity on common carp, but it will also establish threshold for dietary copper toxicity by investigating growth and ionic response, which has not been reported for the fish.

The common carp, a benthic omnivore, is native to Asia and Eastern Europe [11]. Reputed as a popular food fish and a highly cultivable species with year round breeding under tropical and subtropical conditions, the common carp also plays an important role in polyculture systems in seasonal reservoirs and ponds [12]. It is the only exotic carp species that is known to breed naturally in lake. It has high fecundity and hatchability [13].

It has been introduced into environments worldwide and can grow to a maximum length of 5 feet $(1.5 \mathrm{~m})$, a maximum weight of over $80 \mathrm{lb}(37.3 \mathrm{~kg})$, and an oldest record age of at least 65 years [14]. This age longevity of common carp makes it good for chronic toxicity test. Similarly, although they are very tolerant of most condition, the common carp prefer large bodies of show or standing water and soft, vegetable sediments. This makes it not unaffected by pollution from heavy metals since they eat anything near bank and bottom, thus ingesting contaminated food and water during feeding [15].

Fish unlike most terrestrial animal, can absorb some minerals, (inorganic elements) not only from their diet, but also from their external aquatic environment [16]. Calcium (ca), sodium ( $\mathrm{Na}$ ), potassium $(\mathrm{k})$, copper $(\mathrm{Cu})$ and other essential minerals are generally derived from the water to satisfy part of the nutritional requirement of fish [17]. Inorganic elements, which are required for the normal life processes of fish, perform the following function: formation of skeletal muscles structures, electron transfer, regulation of acidbase balance/ equilibrium and osmoregulation; they are important component of hormones and enzymes and activate enzymes. Complex biochemical mechanisms control and regulate the uptake, storage, and excretion of various inorganic elements, allowing fish to live in a dynamic equilibrium with their aquatic medium. The electrolytes $\mathrm{Na}^{+}$, $\mathrm{Mg}^{2+}, \mathrm{Ca}^{2+}, \mathrm{Cl}^{-}$and $\mathrm{HCO}_{3}$ play a major role in the osmotic and ionic regulation of extra -and intra cellular fluids in fish [16].

The exchange of ions from the surrounding water across the gill and skin of fish complicates the measurement of mineral requirement; although most essential elements known for terrestrial animals are also considered important for fish, quantitative requirement have been reported for only nine(9) minerals: calcium, phosphorus, magnesium, iron, copper, manganese, zinc, selenium, and iodine [18-21] for selected fish species.

\section{Materials and Methods}

\section{Experimental design}

Common carp were purchased from Oyo state Agricultural Development Programme (ADP) reputable fish farm in Ibadan, Oyo State. They were then placed under laboratory conditions in fish holding tanks with water temperature $27.4 \pm 0.42^{\circ} \mathrm{C}$ and left unfed in the first 2 days to adapt to a change in environment before feeding them with normal diet.117 fish of average weight $19.43 \pm 14.09 \mathrm{~g}$ were then placed in 9 plastics of 52 liters each in a water renewal method and were fed a control diet with no added copper to saturation for 14 days in order to acclimatize them to experimental conditions with 13 fish per tank. While fish in the first three containers remained on the control diet, fish in the second and last three containers were fed copper-loaded diets $(1000 \mathrm{mg} / \mathrm{kg}$ dry weight feed) and (2,000 $\mathrm{mg}$ cupper/kg dry weight feed) respectively for 42 days. This was then was then followed by a 21 -day recovery period with all containers fed the control diet (no added copper) diet. Throughout the experiment fish were fed to satiation twice a day in the morning and evening. Care was taken to ensure no uneaten food remained in the tanks during feeding and copper did not leach from the feed. To achieve these objectives, water was constantly and completely changed daily with fresh well water added and uneaten food removed after satiation was noted. Daily feed intake was calculated by subtracting weight of feed plus container after feeding from feed plus container before feeding. Copper concentrations in the different tank were measured in the analysis of water quality. Growth and nutritional performance in the different treatments were monitored throughout the experiment and the fish randomly sampled from each tank after 42 -day of copper exposure for hematology, tissue ion analysis, and histology. Fish were not fed the day before sampling times in order to empty the gut and to facilitate dissection.

\section{The Diet}

The control diet was purchased from a commercial animal feed dealer (Adom commercial Feeds, Ibadan, Oyo state, Nigeria) with a proximate composition from manufacturer's guidelines shown below:

\section{Dietary Preparations}

The copper-supplemented diet was formulated by starch coating of the commercial feed with copper sulphate. In order to achieve a nominal copper concentration of $1000 \mathrm{mgCukg}^{-1}$ feed $1.1722 \mathrm{~g}$ of $\mathrm{CUSO}_{4} .5 \mathrm{H}_{2} \mathrm{O}$ (Anala R grade, $\mathrm{BDH}$, poole, UK) was dissolved in $35 \mathrm{ml}$ of deionised water with $1.2 \mathrm{~g}$ of starch to bind the copper to the food sticks. The starch solution was gradually sprayed onto $300 \mathrm{~g}$ of the commercial diet and mixed in a container to ensure even mixing of the food. The starch coat dried within minutes, and the copper diet was stored in airtight containers at $-20^{\circ} \mathrm{C}$ to prevent lipid oxidation. The other copper supplemented diet $(2000 \mathrm{mgCu} / \mathrm{kg})$ was also treated, but required higher $\mathrm{CuSO}_{4} 5 \mathrm{H} 2 \mathrm{O}$. In order to achieve a nominal copper concentration of $2000 \mathrm{mgCu} / \mathrm{kg}$ feed, $2.3503 \mathrm{~g}$ of $\mathrm{CuSO}_{4} 5 \mathrm{H} 2 \mathrm{O}$ was also dissolved in $35 \mathrm{ml}$ of deionised water with $1.2 \mathrm{~g}$ of starch to bind the copper to the feed. It was then mixed thoroughly; the starch solution was sprayed onto $300 \mathrm{~g}$ of the pre-treated diet and stored at $-20^{\circ} \mathrm{C}$ after moments of drying. The control diet was similarly treated except that no copper was added. The copper contents of the diets were confirmed 
by Atomic Absorption Spectrophotometry (model 210 VGP) with the following specification for copper detection and analysis:

\section{Growth and nutrition performance}

Growth and nutritional performance was measured and described below:

Briefly, feed intake was calculated, daily for each tank by weighing feed containers before and after feeding. All fish were individually weighed at the start of the experiment and the end of 42 days of exposure. The individual fish weight was used because the periodic sacrifice of fish during the experiment prevented nutritional parameters being calculated from cumulative tank biomass as follows:

- Specific growth rate SGR $\left(\%\right.$ day $\left.^{-1}\right)=\left(\log _{\mathrm{e}} \mathrm{W}_{2}-\log _{\mathrm{e}} \mathrm{W}_{1}\right) /\left(\mathrm{t}_{2}\right.$ $\left.-t_{1}\right) \times 100$

$\mathrm{t}_{1}=$ initial time point before exposure (days)

$\mathrm{t}_{2}=$ final time point after exposure (days)

$\mathrm{W}_{1(\mathrm{~g})}=$ fish weights at $\mathrm{t}_{1}$

$\mathrm{W}_{2(\mathrm{~g})}=$ fish weights at $\mathrm{t}_{2}$

Feed Conversion Ratio $($ FCR $)=\frac{\text { feed intake }(\mathrm{g})}{\text { Weight gain }(\mathrm{g})}$

This was calculated from mean gain in body weight for each treatment for

i) the copper exposure phase (days $0-42$ ),

ii) recovery phase (days $43-63$ )

- Mean weight gain $(\mathrm{g})=$ final weight -initial - weight

- $\quad$ Condition factor $(\%)=\operatorname{weight}(\mathrm{g}) /$ length $\left.^{3}(\mathrm{~cm}) \times 100\right)$

- Hepato-somatic index for each fish (\%) = liver weight (g)/body weight $(\mathrm{g}) \times 100$.

\section{Tissue ion and Moisture analysis}

Tissues for trace metal analysis were oven dried to a constant weights, which were subtracted from the initial weight of each tissue before drying to get the moisture content and then expressed as percentage of initial weight; oven dried samples were then digested in nitric acid and then diluted to volume with distilled water. The samples were analyzed by Atomic Absorption spetrophotometry for copper (at $589.00 \mathrm{~nm}), \mathrm{K}^{+}$(at $766.5 \mathrm{~nm}$ ), $\mathrm{Na}^{+}$(at $589.00 \mathrm{~nm}$ ), and $\mathrm{Ca}^{2+}$ (at 422.7 $\mathrm{nm}$ ) was using flame photometer (model: corning 410).

\section{Results and Discussion}

The physiological effects of dietary copper exposure and recovery on normal diet were studies throughout the entire length of the project. Growth performance, histology, hematology as well as tissue ion and moisture were investigated during the two phase of the experiment (exposure and recovery) water quality was monitored throughout the exposure phase and result showed that all parameters were within the range required and tolerated by common carp.

This study is a first report of chronic dietary copper exposure/ toxicity in common carp; and overall, fish, in this research, accumulated excess copper in the liver and intestine. The results of the experiments are discussions are discussed below with tables showing the effects of dietary copper on each parameter.

\section{Copper accumulation}

Copper accumulations in fish tissue have severally been reported $[5,7,22,23]$. In this study, copper accumulation in common carp also reflected the route of exposure [24], with large increase in copper content of the liver and intestine $[1,23,25]$ and is consistent with previous studies on temperate species such as rainbow trout [26], Atlantic Salmon [25]. The gills showed increased copper accumulation post exposure in the $1000 \mathrm{mgCu} / \mathrm{kg}$ (diet 1) and $2000 \mathrm{mgCu} / \mathrm{kg}$ (diet 2). This cannot be explained by aqueous copper uptake, because gill morphology was normal (NVL) during and post exposure period [7]; rather, it was due to increased intestinal absorption of dietary copper.

Copper accumulation in fish does not depend on dietary level [25], but sodium dependent [27-29] as well as being calcium dependent [30]. In this research the time dependent reduction in the control was sodium and calcium dependent $[27,30]$ with sodium increasing from $257.82 \pm 2.50 \mu \mathrm{mol} / \mathrm{g}$ to $388.14 \pm 1.32 \mu \mathrm{mol} / \mathrm{g}$ and calcium increasing from $499.54 \pm 6.81 \mu \mathrm{molg}^{-1}$ to $1025.94 \pm 9.16 \mu \mathrm{molg}^{-1}$ reducing gill copper from $11.63 \pm 0.37 \mathrm{mgCukg}^{-1}$ to $0.00 \pm 0.00 \mathrm{mgCukg}^{-1}$. Intestinal copper decreased from $14.93 \pm 0.1 \mathrm{mgCukg}^{-1}$ to $0.00 \pm 0.00 \mathrm{mgCukg}^{-1}$ as a result of sodium increasing from $130.30 \pm 5.12 \mu \mathrm{molg}^{-1}$ to 438.72 $\pm 2.44 \mu_{\mathrm{molg}}{ }^{-1}$. The reduction in intestinal calcium was sodium dependent as increasing sodium decreased calcium absorption [31]. Increased gill copper of the $1000 \mathrm{mgCukg}^{-1}$ diet exposed fish during exposure compared to the control was due to copper induced decrease in plasma ion regulatory sodium (Na ATPase activity), which protected fish from direct toxicity effect [32] and could also suggest another pathway other than the common $\mathrm{Na} / \mathrm{Cu}$ apical channel shared between sodium and copper through which copper binds to fish gill [28]. The later reason could be apt due to the fact that, although, inhibition of copper branchial /basolateral $\mathrm{Na}+\mathrm{K}+$ ATPase cannot extrude intracellular $\mathrm{Na}+$ into the blood (that is influx is inhibited), branchial influx of sodium was stimulated into the blood due to decreased plasma sodium from low intestinal uptake [33]. The copper accumulated in the gill of the $1000 \mathrm{mgCukg}^{-1}$ exposed fish could, therefore, show that a second high-affinity mechanism for bronchial copper uptake in the gills was independent of external sodium [34]. In the same vein, reduced gill copper of $2000 \mathrm{mg} \mathrm{Cu} / \mathrm{kg}$ (diet 3) exposed fish was due the fact that since sodium and copper shared similarly apical channel, increasing sodium and copper absorption from the intestine elevated plasma concentration of these two mineral/elements beyond the needs of the fish, bronchial influx of sodium and copper were inhibited [33].

The increased gill copper of the $1000 \mathrm{mgCu} / \mathrm{kg}$ diet (diet 2) compared to the control (diet 1) and the $2000 \mathrm{mgCu} / \mathrm{kg}$ (diet 3) is an indication of the beginning of stress to which fish is subjected and this stress response stimulated branchial sodium influx into the blood [33] with resultants increase in haematocrit (PCV). The increased coppers also showed or reflected systemic copper in the gill as a result of the absorption and distribution of dietary copper to the gill from the intestine [7] whose copper was significantly higher $(p<0.05)$ compared to the control and the $2000 \mathrm{mgCukg}^{-1}$ diet fish. The high intestinal copper of the $1000 \mathrm{mgCukg}^{-1}$ exposed fish reflected the greater roleplayed by intestine in regulating absorption and metabolism of copper [21]. This regulatory role by intestine explained the significant reduction in the intestinal copper of the $2000 \mathrm{mgCu} / \mathrm{kg}$ diet (diet 3) exposed fish compared to the $1000 \mathrm{mgCu} / \mathrm{kg}$ diet (diet 2) fish [26]. In other words, homeostasis is primarily regulated at the intestinal level. The significant increase in liver copper of fish exposed to both elevated dietary copper (1000 and $2000 \mathrm{mgCukg}^{-1}$ reflected its role in copper metabolism and excretion $[1,4]$. The continued copper accumulation 
in post exposure in all tissues indicated possible delayed toxic effects of dietary copper. This has also been reported for Nile tilapia [7].

\section{Tissue Sodium, Potassium and Calcium}

The presence of treatment-dependent changes in tissue ions $(\mathrm{Na}+$, $\mathrm{K}, \mathrm{Ca}$ ) suggest that dietary copper caused major osmotic disturbances which stimulated blood production (high red blood cell, haematocrit) of fish exposed to diet 2(1000 mgCukg-). The time dependent increase in sodium and potassium indicated the ability of common carp to acclimatize to long time dietary copper exposure [24,35] and could also reflect the excretion and detoxification capacity of common carp to copper [35]. The time dependent reduction in gill calcium is sodium dependent [31] which explained the further reduction during elevated dietary exposure to $1000 \mathrm{mgCu} / \mathrm{kg}$ (diet 2) compared to the control as the gill sodium increased. The high level of gill calcium compared to other tissues in all treatments and the low level of intestinal calcium is due to the simple fact that the gill is the major and primary site of calcium absorption even though dietary calcium inclusion exceeded requirement $1-8 \%$ vs. $0.34 \%$ and uptake, while the intestinal contribution to calcium uptake comes to $30 \%$. Similarly the presence of hypercalcaemic hormone, cortisol in the gill. Hanssen et al. [36], has been reported to stimulate hypercalcaemia (high calcium), which is calcitrophic $[37,38]$ making fish capable of surviving extreme hypercalcaemia (up to $10 \mathrm{mmol}-1$ total calcium, $4.5 \mathrm{mmol}-1 \mathrm{Ca}^{2+}$. Intestinal absorption of Calcium is inhibited by stanniocalcin (calcium reducing hormone) which reduces intestinal calcium absorption. The calcitropic action of cortisol (a stress hormone, [9]), independent of stanniocalcin [39] become noticeable only in the long term [33]. This could explain hypocalcaemia observed during the chronic dietary exposure of common carp to copper, which showed their stress response to elevated dietary copper (1000 mgCukg-1 and 2000 mgCukg-1). The post exposure phase was characterized by significant decrease in sodium and potassium in all tissue examined with increasing calcium after all fish were returned or fed normal diet. This reflected the continued calcitropic (hypercalcaemic) stress hormone, cortisol effect on common carp post exposure, which initially protected fish against copper accumulation during the exposure phase, but now induced accumulation of the metal in all tissues post exposure [29]. Increasing cortisol production reflects continued depletion of energy in common after exposure to elevated dietary copper. Similarly, the reduction in sodium accounted for the post exposure increase in all tissue examined of copper concentration post exposure [9]. Table 1 and 2 show ionic response to dietary copper in exposure and recovery phase, respectively.

\section{Moisture}

Although other parameters, including some regulatory ions, were significantly affected by dietary copper exposure and recovery, moisture remained unaffected and has been consistent with other research on copper toxicity [27]. The effects of dietary exposure and recovery of copper on the moisture content are presented in tables 3 and 4 .

\section{Growth and Nutritional Performance}

- Fish exposed to diet (1000 mgCukg-1) showed increase weight gain after 42 and this is reflected in the significant increase in condition factor, \% of body weight, increased feed intake, increased specific growth rate and increased hepatosomatic index, and reduced feed conversion ratio; although the weight gain, specific growth rate and feed conversion ratio were not statistically significant compared with other treatment. The increased weight gain of the diet 2 fish was an indication of the onset of stress-induced increase in hematological indices (hemoglobin, haematocrit and red blood cells), and could be secondary response of fish to irritants. Thus as a physiological mechanism of compensation hemoglobin increased to maintain oxygen supply to the fish which translated to increase in the rate of metabolism induced by $\mathrm{Na} / \mathrm{K}$ ATPase action on blood [40]. Thus fish fed diet 2 tends to increase their feed intake with consequent increase in weight gain observed after 42 days. However, fish fed diet 3 showed a significant decrease in weight gain which is reflected in decreased condition factor,

\begin{tabular}{|c|c|c|c|c|}
\hline & Treatment & Gill & Liver & Intestine \\
\hline \multirow[t]{4}{*}{$\mathrm{Na}$} & Initial & $257.82 \pm 2.50^{a}$ & $132.44 \pm 1.73^{\mathrm{a}}$ & $130.30 \pm 5.12^{a}$ \\
\hline & Diet 1 & $388.14 \pm 1.32^{b}$ & $407.47 \pm 0.29^{b}$ & $438.72 \pm 2.44^{b}$ \\
\hline & Diet 2 & $476.65 \pm 1.60^{c}$ & $306.87 \pm 1.48^{c}$ & $356.65 \pm 0.32^{c}$ \\
\hline & Diet 3 & $427.57 \pm 0.71^{d}$ & $356.78 \pm 0.47^{d}$ & $597.74 \pm 3.89^{d}$ \\
\hline \multirow[t]{4}{*}{ K } & Initial & $226.20 \pm 6.12^{\mathrm{a}}$ & $87.07 \pm 2.25^{\mathrm{a}}$ & $86.48 \pm 0.87^{a}$ \\
\hline & Diet 1 & $246.62 \pm 0.76^{b}$ & $340.17 \pm 1.03^{b}$ & $419.53 \pm 0.59^{b}$ \\
\hline & Diet 2 & $320.40 \pm 1.17^{c}$ & $300.25 \pm 1.03^{c}$ & $420.29 \pm 1.38^{c}$ \\
\hline & Diet 3 & $210.04 \pm 0.18^{d}$ & $321.31 \pm 2.0^{d}$ & $437.3 \pm 0.46^{d}$ \\
\hline \multirow[t]{4}{*}{$\mathrm{Ca}$} & Initial & $499.54 \pm 6.81^{a}$ & $4.40 \pm 0.06^{a}$ & $44.02 \pm 1.15^{\mathrm{a}}$ \\
\hline & Diet 1 & $1025.94 \pm 9.16^{b}$ & $62.60 \pm 1.45^{\mathrm{b}}$ & $27.08 \pm 0.85^{\mathrm{b}}$ \\
\hline & Diet 2 & $644.17 \pm 0.10^{c}$ & $3.27 \pm 0.03^{c}$ & $3.21 \pm 0.02^{c}$ \\
\hline & Diet 3 & $1420.94 \pm 3.53^{d}$ & $26.48 \pm 0.75^{d}$ & $20.84 \pm 0.09^{d}$ \\
\hline \multirow[t]{3}{*}{${ }^{*} \mathrm{Cu}$} & Diet 1 & $0.00 \pm 0.00^{\mathrm{ab}}$ & $34.67 \pm 1.00^{\mathrm{ab}}$ & $0.00 \pm 0.00^{b}$ \\
\hline & Diet 2 & $15.67 \pm 0.33^{c}$ & $152 \pm 1.15^{c}$ & $267.67 \pm 1.76^{c}$ \\
\hline & Diet 3 & $0.00 \pm 0.00^{\mathrm{b}}$ & $247.47 \pm 2.19^{d}$ & $55.67 \pm 1.20^{d}$ \\
\hline
\end{tabular}

Data are means \pm S.E. ( $n=3$ per value), expressed in $\mu \mathrm{mol} / \mathrm{g}$ of dry weight fish Letters with the same superscript in the same column are not significant $(p>0.05)$. *Values of $\mathrm{Cu}$ are expressed in $\mathrm{mgCu} / \mathrm{kg}$ of fish

Table 1: Sodium, Calcium and Potassium content in gills, liver and intestine of common carp fed recovery diet 1 (control), diet 2 and diet 3 after 42 days.

\begin{tabular}{lllll}
\hline & Treatment & Gill & Liver & Intestine \\
\hline $\mathrm{Na}$ & Diet 1 & $388.14 \pm 1.32^{\mathrm{a}}$ & $407.47 \pm 0.29^{\mathrm{a}}$ & $438.92 \pm 2.44^{\mathrm{a}}$ \\
& Diet 2 & $300.13 \pm 7.53^{\mathrm{b}}$ & $281.28 \pm 7.67^{\mathrm{b}}$ & $260.99 \pm 7.72^{\mathrm{b}}$ \\
& Diet 3 & $179.79 \pm 6.32^{\mathrm{c}}$ & $272.58 \pm 6.32^{\mathrm{c}}$ & $619.72 \pm 3.83^{\mathrm{c}}$ \\
$\mathrm{K}$ & Diet 1 & $246.62 \pm 0.76^{\mathrm{a}}$ & $340.17 \pm 1.03^{\mathrm{a}}$ & $419.53 \pm 0.59^{\mathrm{a}}$ \\
& Diet 2 & $171.35 \pm 5.91^{\mathrm{b}}$ & $220.79 \pm 3.7^{\mathrm{b}}$ & $284.73 \pm 3.71^{\mathrm{b}}$ \\
& Diet 3 & $225.90 \pm 3.71^{\mathrm{c}}$ & $206.3 \pm 2.98^{\mathrm{c}}$ & $318.82 \pm 3.72^{\mathrm{c}}$ \\
$\mathrm{Ca}$ & Diet 1 & $1025.94 \pm 9.16^{\mathrm{a}}$ & $62.60 \pm 1.45^{\mathrm{a}}$ & $27.08 \pm 0.85^{\mathrm{a}}$ \\
& Diet 2 & $1036.32 \pm 4.4^{\mathrm{b}}$ & $23.292 .20^{\mathrm{b}}$ & $44.91 \pm 2.88^{\mathrm{b}}$ \\
& Diet 3 & $1585.24 \pm 3.63^{\mathrm{c}}$ & $23.29 \pm 2.20^{\mathrm{c}}$ & $10.81 \pm 2.20^{\mathrm{c}}$ \\
& & & & \\
${ }^{*} \mathrm{Cu}$ & Diet 1 & $0.00 \pm 0.00^{\mathrm{a}}$ & $34.6 \pm 1.00^{\mathrm{b}}$ & $0.00 \pm 0.00^{\mathrm{a}}$ \\
& Diet 2 & $55.42 \pm 0.25^{\mathrm{b}}$ & $267.22 \pm 0.5^{\mathrm{b}}$ & $331.43 \pm 0.83^{\mathrm{b}}$ \\
& Diet 3 & $364.49 \pm 5.22^{\mathrm{c}}$ & $290.99 \pm 0.70^{\mathrm{c}}$ & $78.02 \pm 0.87^{\mathrm{c}}$ \\
\hline
\end{tabular}

Data are means \pm S.E ( $n=3 /$ value), expressed as $\mu \mathrm{mol} / \mathrm{g}$

Letters with the same subscript in the same column are not significant $(p>0.05)$

*Values of $\mathrm{Cu}$ are expressed in $\mathrm{mgCu} / \mathrm{kg}$ of fish

Table 2: Sodium, Calcium and Potassium content in gills, liver and intestine of common carp fed recovery diet for 21 days. 
specific growth rate, and an increased feed conversion ratio compared with other treatments. Mortality was recorded in the $2000 \mathrm{mgCukg}^{-1}$ diet (diet3) exposed treatment within 3 weeks. Several authors have noted reduction in growth rate during dietary copper exposure in fish [8]. But others have not $[5,26]$. Reduced growth rate have been observed in Nile tilapia fed $2000 \mathrm{mgCukg}^{-1}$ [7] which is consistent with this research on common carp fed $2000 \mathrm{mgCukg}^{-1}$ (diet3). The recovery phase was characterized by decrease in feed intake by fish fed 1000 $\mathrm{mgCukg}^{-1}$ pre-exposure. This was reflected in reduced weight gain, specific growth rate, condition factor and increased feed

\begin{tabular}{llll}
\hline Treatment & Gill & Liver & Intestine \\
\hline Initial & $73.2 \pm 1.20^{\mathrm{a}}$ & $71.50 .40^{\mathrm{a}}$ & $75.21 .04^{\mathrm{a}}$ \\
Diet 1 & $74.2 \pm 1.80^{\mathrm{a}}$ & $76.12 .77^{\mathrm{b}}$ & $72.91 .43^{\mathrm{a}}$ \\
Diet 2 & $69.5 \pm 5.64^{\mathrm{a}}$ & $62.1 \pm 5.24^{\mathrm{a}}$ & $76.0 \pm 1.43^{\mathrm{a}}$ \\
Diet 3 & $76.1 \pm 1.62^{\mathrm{a}}$ & $67.65 .42^{\mathrm{a}}$ & $72.43 .03^{\mathrm{a}}$ \\
\hline
\end{tabular}

Data are means \pm S.E ( $n=3$ per value), expressed as percentage $(\%)$

Letters with the same subscript in the same column are not significant different $(p>0.05)$.

Table 3: Tissue moisture during copper exposure for 42 days.

\begin{tabular}{llll} 
Treatment & Gill & Liver & Intestine \\
\hline Diet 1 & $77.5 \pm 1.81^{\mathrm{a}}$ & $78.03 \pm 1.82^{\mathrm{a}}$ & $74.3 \pm 4.46^{\mathrm{a}}$ \\
Diet 2 & $75.3 \pm 3.20^{\mathrm{a}}$ & $78.63 \pm 3.19^{\mathrm{a}}$ & $75.9 \pm 2.00^{\mathrm{a}}$ \\
Diet 3 & $79.5 \pm 6.44^{\mathrm{a}}$ & $76.3 \pm 7.13^{\mathrm{a}}$ & $73.6 \pm 18.30^{\mathrm{a}}$ \\
\hline
\end{tabular}

Data are means \pm S.E ( $n=3$ per value), expressed as percentage (\%)

Letters with the same subscript in the same column are not significant different $(p>0.05)$

Table 4: Tissue moisture during recovery phase on normal diet from 21 days

\begin{tabular}{|c|c|c|}
\hline \multicolumn{2}{|l|}{ Parameter } & \multirow{2}{*}{$\begin{array}{l}\text { Exposure } \\
8.50 \pm 5.25^{a}\end{array}$} \\
\hline Weight gain (g) & $\mathrm{D}_{1}$ & \\
\hline & $\mathrm{D}_{2}$ & $16.2 \pm 5.25^{b}$ \\
\hline & $\mathrm{D}_{3}$ & $-1.67 \pm 4.37^{c}$ \\
\hline \multirow[t]{3}{*}{ Feed Conversion Ratio } & $\mathrm{D}_{1}$ & $0.46 \pm 0.18^{a}$ \\
\hline & $\mathrm{D}_{2}$ & $0.18 \pm 0.03^{a}$ \\
\hline & $\mathrm{D}_{3}$ & $0.51 \pm 0.25^{a}$ \\
\hline \multirow{3}{*}{$\begin{array}{l}\text { Specific Growth Rate } \\
(\% \text { day }-1)\end{array}$} & $\mathrm{D}_{1}$ & $0.07 \pm 0.05^{\mathrm{a}}$ \\
\hline & $\mathrm{D}_{2}$ & $0.14 \pm 0.02^{a}$ \\
\hline & $\mathrm{D}_{3}$ & $-0.09 \pm 0.10^{a}$ \\
\hline \multirow[t]{3}{*}{ Condition factor (\%) } & $\mathrm{D}_{1}$ & $1.45 \pm 0.02^{\mathrm{a}}$ \\
\hline & $\mathrm{D}_{2}$ & $1.60 \pm 0.07^{b}$ \\
\hline & $\mathrm{D}_{3}$ & $1.41 \pm 0.05^{a}$ \\
\hline \multirow[t]{3}{*}{ Hepatosomatic Index (\%) } & $\mathrm{D}_{1}$ & $0.99 \pm 0.07^{a}$ \\
\hline & $\mathrm{D}_{2}$ & $1.47 \pm 0.04^{b}$ \\
\hline & $\mathrm{D}_{3}$ & $1.74 \pm 0.12^{b}$ \\
\hline \multirow{3}{*}{$\begin{array}{l}\text { Mean Ration Size } \\
\text { (\% body weight) }\end{array}$} & $\mathrm{D}_{1}$ & $0.84 \pm 0.04^{a}$ \\
\hline & $\mathrm{D}_{2}$ & $1.08 \pm 0.04^{b}$ \\
\hline & $\mathrm{D}_{3}$ & $1.06 \pm 0.07^{b}$ \\
\hline
\end{tabular}

Data are means \pm S.E ( 33 per value), except for ration size where $n=$ number of daily ration size

Letters with the same subscript in the same column are not significant $(p>0.05)$

Table 5: Growth and Nutritional Performance of common carp fed control (diet 1)

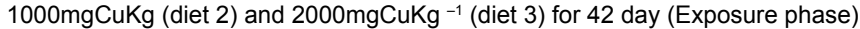

\begin{tabular}{|c|c|c|}
\hline Parameter & Treatment & Recovery. \\
\hline \multirow[t]{3}{*}{ Weight gain $(\mathrm{g})$} & $\mathrm{D}_{1}$ & $5.30 \pm 0.60^{a}$ \\
\hline & $\mathrm{D}_{2}$ & $3.67 \pm 2.97^{\mathrm{a}}$ \\
\hline & $D_{3}$ & $0.83 \pm 1.87^{a}$ \\
\hline \multirow[t]{3}{*}{ Feed Conversion Ratio } & $\mathrm{D}_{1}$ & $0.26 \pm 0.03^{a}$ \\
\hline & $\mathrm{D}_{2}$ & $1.60 \pm 0.85^{\mathrm{a}}$ \\
\hline & $\mathrm{D}_{3}$ & $0.28 \pm 0.37^{a}$ \\
\hline Specific Growth Rate & $\mathrm{D}_{1}$ & $0.14 \pm 0.03^{a}$ \\
\hline \multirow[t]{2}{*}{$(\%$ day -1$)$} & $\mathrm{D}_{2}$ & $0.090 .02^{a}$ \\
\hline & $\mathrm{D}_{3}$ & $0.02 \pm 0.05^{\mathrm{a}}$ \\
\hline \multirow[t]{3}{*}{ Condition factor (\%) } & $\mathrm{D}_{1}$ & $1.54 \pm 0.02^{\mathrm{a}}$ \\
\hline & $\mathrm{D}_{2}$ & $1.39 \pm 0.01^{\mathrm{b}}$ \\
\hline & $\mathrm{D}_{3}$ & $1.43 \pm 0.02^{b}$ \\
\hline \multirow[t]{3}{*}{ Hepatosomatic Index (\%) } & $\mathrm{D}_{1}$ & $1.240 .02^{\mathrm{a}}$ \\
\hline & $\mathrm{D}_{2}$ & $1.65 \pm 0.02^{b c}$ \\
\hline & $\mathrm{D}_{3}$ & $1.84 \pm 0.03^{d}$ \\
\hline Mean Ration Size & $\mathrm{D}_{1}$ & $0.90 \pm 0.04^{a}$ \\
\hline \multirow[t]{2}{*}{ (\% body weight) } & $\mathrm{D}_{2}$ & $0.90 \pm 0.03^{a}$ \\
\hline & $\mathrm{D}_{3}$ & $0.89 \pm 0.06^{a}$ \\
\hline
\end{tabular}

*Data are means \pm S.E ( 3 per value), except for ration size where $n=$ number of daily ration size

Letters with the same subscript in the same column are not significant $(p>0.05)$

Table 6: Growth and Nutritional Performance of common carp fed control diet for 21 days.

conversion ratio post exposure. The $2000 \mathrm{mgCukg}^{-1}$ diet (diet 3) fed fish also showed reduced weight, specific growth rate and a significantly reduced condition factor post exposure. The effects of dietary exposure and recovery on growth are shown in Tables 5 and 6.

\section{Conclusion}

In conclusion, copper, although essential in the diet of fish, involved in many physiological and developmental as well as growth, could be deleterious when dietary inclusions exceed that required for proper function of the body in view of its major effects in ionic misbalances in common carp (Cyprinus carpio), which could trigger a whole lot of physiological and enzyme processes in the body, necessary for growth and development. Further research is necessary to determine dietary requirement of tropical fish species, including common carp (Cyprinus carpio).

\section{Acknowledgement}

Many thanks go to God for giving us the strength to complete this work with the needed time frame. The author of this paper, Dr Ajani, EK, of the department of Wildlife and Fisheries Management, University of Ibadan, Nigeria, deserves the accolades for his outstanding contribution both academically, technically and financially towards the completion of this work.

\section{References}

1. Hinton DE, Lauren JL (1990) Integrative histopathological approaches to detecting effects of environmental stressors on fishes. Am Fish Soc Sym 8 : 51-56.

2. Bennett WA, Sosa A, Beitinger TL (1995) Oxygen tolerance of fathead minnows previously exposed to copper. Bull Environ Contam Toxicol 55: 517-524.

3. Linder, MC, Goode CA (1991) Biochemistry of copper(vol 10). Plenum Press New York. 
4. Lundebye AK, Berntssen MHG, Wendelear Bonga SE, Maage A (1999) Biochemical and physiological response in Atlantic Salmon (Salmo salar) following dietary exposure to copper and cadmium. Mar Pollut Bull 39: 137144

5. Lanno RP, Slinger SJ, Hilton JW (1985) Maximum tolerable and toxicity levels of dietary copper in rainbow trout (Salmo gairdneri Richardson). Aquaculture 49: $257-268$.

6. Ashley LM (1972) Nutritional Pathology. Academic Press New York.

7. Shaw BJ, Handy RD (2006) Dietary Copper exposure and Recovery in Nile Tilapia, Oreochromis niloticus. Aquat Toxicol 76: 111-121.

8. Clearwater SJ, Farag AM, Meyer JS (2002) Bioavailability and Toxicity of diet borne copper and zinc to fish. Comp Biochem Physiol 132: 269-313.

9. Karan V, Vitorović S, Tutundzić V, Poleksić V (1998) Functional enzymes Activity and Gill histology of carp after copper sulfate Exposure and Recovery. Ecotoxicol Environ Saf 40: 49-55.

10. Svobodova Z, Vykusova B, Machova J (1994) The effedts of pollutants on seleted haematological and biochemical parameters in fish.IN:r.Muller AND $r$, Lloyd(eds), sublethal and chronic effects of pollutants on freshwater fish. Fishing News Books, London

11. Taylor J, Mahon R (1977) Hybridisation of Cyprinus carpio and Carassius auratus, the first two exotic species in the lower Laurentian Great lakes. Environ Bio fishes 1: 205-208.

12. Chakrabarty RD (1982) Polyculture Principles and Practices. Journal of Inland Fisheries 1: 30-40

13. Nathaniel S, Edirisinghe $U$ (2001) Abundance and Aspects of the Reproductive Biology of Common Carp (Cyprinus Carpio) in an upland Reservoir in Srilanka. Asian Fisheries Science 14: 343-351.

14. Panek FM (1987) Biology and Ecology of carp page 1-16 in cooper, E,L. (editor) Carp in North America. American fisheries society, Bethesda, Maryland, USA.

15. Alabaster JS, Lloyd R (1980) Water Quality Criteria for Freshwater Fish. Butterworths 297.

16. Lall SP (1989) The minerals Pp 210-257 in fish nutrition, 2nd ed, J.E Halver, ed. New York: Academic Press.

17. Phillips AM, Podoliak HA, Poston HA, Livingston DC, Dumas RF, Thoesen RW (1959) Cortland Hatchery Rep 28: 17 - 21.

18. Gatlin DM III, Wilson RP (1986b) Dietary copper requirement of fingerling channel catfish. Aquaculture 54: 277-285.

19. Gatlin DM 3rd, Wilson RP (1984c) Dietary selemium requirement of fingerling channel catfish. J Nutr 114: 627-633.

20. Bell JG, Cowey CB (1989) Digestibility of dietary selenium from fish meal, selenite selenomethionine and selenocystine in Atlantic Salmon (Salmo Salar). Aquaculture 81: 61-68.

21. Lall SP, Hines JA (1987) Iron and Copper requirement of Atlantic salmon (Salmo salar) grown in Seawater. Paper presented at the international symposium on feeding and Nutrition of fish, Bergen, Norway, August 23-27.

22. Pere, Pihan JC (1991a) Copper LC50 to Cyprinus Carpio: Influence of hardness, seasonal variation proposition of maximum acceptable toxicant concentration. Env Toxicol 12: 161-167.

23. Celechovska O, Svobodova Z, Zlabek V, Macharackova B (2007) Distribution of metals in tissue of common carp (Cyprinus carpis L.) ACTA VET BRNO 76 S93-S100

24. Kamunde C, Grosell M, Higgs D, Wood CM (2002) Copper metabolism in actively growing rainbow trout (Oncorhynchus mykiss). Interactions between dietary and waterborne copper uptake. J Exp Biol 205: 279-290.

25. Bertssen MHG, Lundebye A, Mange A (1999) Effects of elevated dietary copper concentrations on growth, feed utilization and nutritional status of Atlantic Salmon (Salmo Salar L.) fry. Aquaculture 174: 167-181.

26. Kamunde CN, Grosell M, Lott JN, Wood CM (2001) Copper metabolism and gut morphology in rainbow trout (Oncorhynchus mykiss) during chronic sublethal dietary copper exposure. Can J Fish Aquat Sci 58: 293-305.

27. Kjoss VA, Grosell M, Wood CM (2005) The influence of Dietary Sodium on Copper accumulation in Juvenile Rainbow Trout exposed to combined Dietary and waterborne copper in soft water. Arch Environ Contam Toxicol 49:520-527.
28. Pyle GG, Kamunde CN, McDonald DG, Wood CM (2002) Dietary sodium inhibits aqueous copper uptake in rain bow trout(Oncorhychus mykiss). J Exp Biol 206: 609-618.

29. Erickson RJ, Benoit DA, Matson VR, Nelson HP, Leonard EN (1996) The effect of water chemistry on the toxicity of copper to fathead minnows. Environ Toxicol Chem 15: 181-193.

30. Mohsen A, Mamdouh AA, Monammad HA, Saleh FM (2006) The use of calcium pre-exposure as a protective agent against environmental copper toxicity for juvenile Nile tilapia, Oreochromis niloticus (L). Aquaculture 264: 236-246.

31. Flik G, Verbost PM (1993) Calcium transport in fish gills and intestine. J Exp Biol 184: 17-29.

32. De Boeck G, De Wachter B, Vlaeminck A, Blust R (2003) Effects of cortiso treatment and /on sub lethal copper exposure on copper uptakes and hea shock protein levels in common carp, Cyprinus carpio. Environ Toxicol Chem 22: $1122-1126$.

33. Salman NA, Eddy FB (1987) Response of chloride cell numbers and gill $\mathrm{Na}$ $\mathrm{K}^{+} /$ATPase activity of freshwater rinbow trout (Salmo gairdneri) to salt feeding. Aquaculture 61: 41-48.

34. Grosell M, Wood CM (2002) Copper uptake across rainbow trout gills: mechanisms of apical entry. J Exp Biol 205: 1179-1188.

35. McDonald DG, Wood MC (1993) Branchial mechanisms of acclimation to metals in freshwater fish. In: Fish ecophysiology (ed. J.C. Rankin and F.B. Jensen), Pp 297-321. London, UK: Chapman and Hall.

36. Hanssen RG, Lafeber FP, Flik G, Wendelaar Bonga SE (1989) Ionic and total calcium levels in blood of the European eel (Anguilla anguilla): effects of stannioctomy and hypo-calcium replacement therapy. J Exp biol 141: 177-186

37. Flik G, Perry SF (1989) Cortisol stimulates whole body calcium uptake and the branchial calcium pump in fresh water rainbow trout. J Endocrinol 120:75-82.

38. Flik G, Fenwick JC, Wendelaar Bonga SE (1989) Calcitropic actions of prolactin in fresh water North American eel (Anguilla rostrata Lesueur). Am J Physio 257: R74-R79.

39. Verbost PM, Flik G, Fenwick JC, Greco AM, Pang PKT, et al. (1993c) Branchial Calcium, uptake: possible mechanisms of control by stanniocalcin. Fish Physio Biochem 11: 205-215.

40. Garnong WF (1979) Reviews of medical physiology 9th Ed. 618pp. 